\title{
Hydro-Hegemony Framework: A study of the India Pakistan trans- boundary water competition and cooperation
}

\author{
Munawar Hussain*1 ${ }^{\text {Munazza Khalid }}{ }^{1-2} \mid$ Sumeera Imran ${ }^{3}$
}

1. Area Study Center for South and North America, Quaid-e-Azam University, Islamabad, Pakistan.

2. Department of Aerospace Sciences and Strategic Studies, Air University, Islamabad, Pakistan.

3. Department of International Relations, National Defence University, Islamabad, Pakistan.

*Correspondence Emails: mhussain@qau.edu.pk | hussain.munawar76@yahoo.com

\begin{abstract}
After the independence of Pakistan and India in 1947, both the newly established states submerged in many tensions leading to competition in many areas. One such area is the hydro competition between the two closely bordering states. Within this context, India and Pakistan kicked by perianal security dilemma at all levels. India is diverting water from western rivers, which is not permissible for India in Indus Water Treaty (IWT). The Purpose of this study is to find out the reason/s that why India is behaving in this way? This is applied research within the context of Hydro-Hegemony Framework (HHF) theory. According to the theory, India is behaving hydrohegemonically because of the three reasons stated by Hydro-Hegemony Framework; firstly, because of Indian advantageous upper-riparian geographical position; secondly, because of Indian superior technical potential and ability to construct a lot of dams; thirdly power asymmetry exists between India and Pakistan. India because of these three main reasons is desirous to get "Consolidated Water Control" over three western rivers assigned to Pakistan by Indus Water Treaty. Indian endeavours to get water dominance would complicate its relations with Pakistan. Indian hydrohegemony would impact Pakistan's economy, hydro-power generations projects, agriculture sectors and domestic hydro-usage.
\end{abstract} Article History

Received:

March 3, 2021

Last Revised:

June 23, 2021

Accepted:

June 24, 2021

Published: June 30, 2021

Keywords: Hydro-Hegemony Framework, Indus Water Treaty, hydro-relations, transboundary water, water competition, water control, water cooperation, water-conflict.

How to Cite: Hussain, M., Khalid, M., \& Imran, S. (2021). Hydro-Hegemony Framework: A study of the India Pakistan trans-boundary water competition and cooperation. Liberal Arts and Social Sciences International Journal (LASSIJ), 5(1), 537-553. https://doi.org/10.47264/idea.lassij/5.1.35

Publisher's Note: IDEA PUBLISHERS (IDEA Journals Group) stands neutral with regard to the jurisdictional claims in the published maps and the institutional affiliations.

Copyright: () 2021 The Author(s), published by IDEA PUBLISHERS (IDEA Journals Group). This is an Open Access article published under the Creative Commons Attribution-NonCommercial 4.0 International License (http://creativecommons.org/licenses/by-nc/4.0/) 


\section{Introduction}

Water is becoming scares on daily basis throughout the world and competition between Pakistan India is extended in water domain. States are amassing more water by developing more dams to avoid future water scarcity. Indus Water Treaty (IWT) was signed to resolve the water issues between India and Pakistan. However, due to the Indian Hydro-hegemonic nature it is mostly violating IWT and proposing and developing hydro-projects over three western rivers assigned to Pakistan. India is diverting water from western rivers which is not allowed for India according to the IWT. The research problem is that though IWT is agreed between both states but still India is violating the provisions of IWT. The Purpose of this study is to find out the reason/s that why India is behaving in this way? The significance and the scope of the study is that it is applied research where Hydro-Hegemony Framework theory is used to address the question.

The research methodology is based on deductive approach, where theoretical framework of Hydro-hegemony is used. According to the theory, India is behaving hydro-hegemonically because of the three reasons stated by Hydro-Hegemony Framework; firstly, because of Indian advantageous upper-riparian geographical position; secondly, because of Indian superior technical potential and ability to construct a lot of dams; thirdly power asymmetry exists between India and Pakistan. The outcome of the research is that India because of these three main reasons are desirous to get "consolidated water control" over three western rivers assigned to Pakistan by IWT. Indian endeavours to get water dominance would complicate its relations with Pakistan. Indian hydro-hegemony would impact Pakistan's economy, hydro-power generations projects, agriculture sectors and domestic hydro-usage. The structure of the study includes different sections such as, introduction, research methodology, literature review, Theory of Hydro-hegemony, three pillars of theory, Criteria of theory, Application of theory, three forms of hydro control and Conclusion.

\section{Literature review}

Hydro-relations of India and Pakistan are multifaceted, volatile, and complicated since independence because of the Indian hydro-hegemon nature and the Transboundary River existing between them. Transboundary Rivers or international waters are those form of rivers that are having boundary between two or more countries. These rivers are also termed as contiguous rivers or successive rivers. In short, Contiguous/Successive/Transboundary rivers flow from one country into another. Definition of Transboundary Rivers includes surface and underground waters in the form of canals, lakes and international tributary rivers" (Allouche, 2005). Vienna Congress defined transboundary rivers in 1815, as "les Puissances dont les Etats sont séparés ou traversés par une même rivière navigable" (Allouche, 2005). This definition describes the characteristics of rivers as those which separate two states. In India and Pakistan case, Transboundary Rivers are Jhelum, Chenab, Indus, Ravi, Sutlej, and Beas.

Water is of significant for human life, but its scarcity instigated a new sort of hydro-hegemon behaviour of states to amass more water for their present and future usage especially in the transboundary water domain. This water struggle endangered the right of lower riparian states. In South Asia, India is the upper riparian and a hostile and non-cooperative state whose (emerging economy and regional power) ambitions forced it to amalgamate more water resources. India is having water clashes with most of its neighbouring states including 
Bangladesh, Nepal, and Pakistan. India as an upper-riparian and its increasing population prompted it to develop more dams and hydro-projects to fulfil its agriculture, domestic and electricity demand to develop its economy and to fulfil the country's requirement and the need of its population.

India-Pakistan relations since independence were antagonistic. Both states fought three major wars and are continuously facing traditional as well as non-traditional security challenges. Water security is the emerging domain that is adversely affecting their relations. India as an upper riparian state mostly act as hydro-hegemon in Indus basin region. Indus River is the major water supplier resource to Pakistan. Pakistan's $80 \%$ of water supplies comes from Indus River and other $20 \%$ water resource demand fulfil from Kabul River Afghanistan. Indus River originates from Tibetan region and flows from China, Kashmir and Pakistan and eventually falls in the Arabian Sea. Its total length is 3180 Kilometres.

Water conflict evolved after the independence of Pakistan and India and the formation of two independent states out of one Indian Subcontinent. States were created but water boundaries were not separated, and the issue of water conflict was started when Indian hegemonic nature was noticed when it used water as a weapon in fighting Kashmir war (Anunciaçao, 2013). It halted water supply to Pakistan in April 1948 (Mirza, 2016) and restored partial supply of water in May 1948 (Ranjan, 2016). In October 1948 agreement was signed to continue the flow of water to Pakistan on the condition that Pakistan have to pay seigniorage but in July 1950 Pakistan curtailed paying seigniorage until India restored Kashmir talk. "David Lilienthal, former Chairman of Atomic Energy Commission, USA visited the two countries in 1951" (Ranjan, 2016) and suggested both states to agree upon the framework of operating Indus basin river system. Later, Eugene R. Black who was former President of the World Bank visited both South Asian nations and presented mediatory role. In February 1954, World Bank anticipated the proposal of dividing three rivers to each state.

Some cooperation was noticed in September 1960 when hydro-tension between India and Pakistan was resolved by signing IWT. "Jawaharlal Nehru, Field Marshal Ayub Khan, and W. A. B. Illif, signed IWT in September 1960 in Karachi" and finally the treaty allocated three rivers to each country (Mirza, 2016). India got authority over Ravi, Sutlej and Beas River as these are the three eastern rivers. However, Pakistan received authority over the usage of three western rivers that includes; Jhelum, Chenab and Indus (Nazakat, 2015). Stephen P. Cohen considered Indus Waters Treaty as a perfect model to be adopted for forthcoming regional cooperation in different sectors including energy, environmental concerns, and water resources management" (Iqbal, 2010). Because IWT has survived through three wars and many conflicts. However, it is suggested that it must be re-negotiated to resolve the existing loopholes and deficiencies in it.

Indian hostile endeavours of constructing dams and initiating hydro-projects over three western rivers has worsened and complicated India-Pakistan relations. Pakistan has raised few objections over Indian different projects over western rivers. These disputed projects are Baglihar Hydro Power Project (that is termed as BHP), Wullar project, Tulbul Navigation Project (or TNP) and Kishenganga Project (Sridhar, 2008). India is trying to assert its hegemony over these rivers by altering the water flowing course. Main reason behind dispute over Indus water was that major rivers of Indus basin passes through disputed territory of Jammu and Kashmir, which is bone of contention between India and Pakistan since 1947. A resource and water politics is ongoing in Kashmir. 
In short, India-Pakistan are rival states since independence. Both indulged in and unending competition in every aspect to compete other. This competition is noticed in their hydro relation domain. Hydro-competition is not new. It was started since the time of independence. At the time of independence territorial boundaries were distributed without distributing water boundaries. India is determined to be a regional hegemon and is aspirant and striving to get the status of regional hegemon. India is also aspiring to be a hydro-hegemon. The facts existing in hydro-discourse illustrate the Indian hydro-hegemon nature. Nature is supporting it to be hydro hegemon especially, Indian geographical location. India is amalgamating more and more power to be a hydro-hegemon.

IWT is considered as "divorce settlement and a riparian iron curtain rather than a cooperative accord" (Michel, 2020). Because still India is constructing dams on Pakistani allocated rivers. Pakistan is having reservation over these constructions because these Indian installations are having detrimental effect for Pakistan's economy. Indian construction of these dams can either "withhold water to foster famine, or suddenly releasing it to provoke flood" (Michel, 2020). Indus water issues are having impact for national security as well. Water issue is considered very important in India Pakistan relations. Due to the significance of the Indus water once "Lashkar-e-Taiba threatened to bomb India's dams and menace war to recapture Pakistan's rightful water" (Michel, 2020). Later, Pakistani Former President Asif Ali Zardari cautioned India in 2009 that, it could be better to resolve Indus water issues at earliest otherwise it could lead towards extremism and terrorism. Pakistani former Army Chief also declared that "Pakistan's military posture will remain India-centric until the Kashmir and water disputes are settled" (Michel, 2020).

In 2016, the Indian Prime Minister Narendra Modi stated that "blood and water can't flow together" (Michel, 2020). Indian new Joint Doctrine of the Indian Armed Forces identifies that "climate change, environmental disasters, and rising competition for natural resources as real conflict risks and potential geopolitical threats shaping India's security environment" (Michel, 2020). The water shortage is not only an inter-state issue between India and Pakistan. It is faced at intra-state level as well. Sindh is accusing Punjab of providing less water. At regional level, water politics is ongoing. Afghanistan is developing dams on Kabul River that decreases water flow to Pakistan. India is assisting Afghanistan in developing those reservoirs. However, Pakistan is considering these initiatives as an encircling effort of India. Indian three-quarters of the Indus's annual flow enters India from China. It is the major concern for India because China is the up-streamer state, and it is developing many "hydropower projects under the Belt and Road Initiative" in the contested Kashmir region that will benefit Pakistan in future (Michel, 2020).

The global water scarcity zone comprised of more than $40 \%$ of the area worldwide. Transboundary water flows across thirty-nine states that resulted into water-based interdependence (Angelakis et al., 2021,). Water conflicts have been noticed since ancient times. Thucydides proclaimed that Spartan were defeated in Pylos because of the shortage of water and food. In Peloponnesian war Athenian contaminated water. It is concluded that the best strategy to win a war is to cut the water supply at the time of war/conflict. Indian water demand will be doubled by 2030. The interstate water conflict between India and Pakistan on distribution of hydro-resources was dated back in $19^{\text {th }}$ century. Anderson Commission resolved the conflict in 1935. Later, Rao Commission again resolved the water conflict in 1942. These conflicts prolonged in the post-independence era. Indian hegemonic nature provoked it to demand sovereign right for using water. World Bank mediated on water issue and the later 
IWT was signed amid India and Pakistan. India is violating the treaty by developing different controversial projects. Even, India was ready to withdraw from treaty (from December 2001 till June 2002) and Pakistan was announcing to use nukes because of prevailing water conflict. Later, the issue was resolved. Succinctly, water remained source of concern between both states (Angelakis et al., 2021).

The sovereign control of the states over water can be understand by analysing two different types of approaches. State can either adopt "absolute territorial sovereignty" framework or "absolute territorial integrity" theory. The former perspective provides upstream state absolute right of sovereignty over water usage in its territorial domain. The later approach refrains the upstream state from developing projects over rivers assigned to downstream states (Javed et al., 2021, p.197). According to these perspectives, India is applying the former approach towards its development of water project and Pakistan is considering the later approach appropriate for its water policy, objectives and goals. It will help in Pakistan's political manifestation and policy perspective adaptation. Pakistan's population increased twelvefold since independence.

Javed et al. (2021) predicted that Pakistan's population will be around 355 million till 2050. Population growth demands excessive water supply. Currently 40-55 million Pakistani face drinking water shortage. India and Pakistan are facing transboundary water issue that may lead towards water war. Fear of water blockage and overpopulation dictates states to act offensively. Environmental and climate change also resulted into water scarcity (Qureshi, 2017). India is trying to control water that is assigned to Pakistan because of its hydro-dominion and its favourable location in the upstream region (Price et al., 2014). Indian water grasp and dam construction begun in 1999 (Javed et al., 2021). India in 2008 filled its dams that resulted into water shortage in Chenab River and Pakistan faced crop loss at that time (Javed, Rasool \& Mustafa, 2021). Indian stance on Baglihar dam is that it is a legal project that is not violating IWT but Pakistan is considering it the violation of IWT. It is required that multiple actors would coordinate to resolve water issue. Because water is source of concern for farmers, industrial workers, citizens, local, national and provisional government for any state. In short water issue is having economic, social, political and legal implications. Private sector involvement in water management is less in South Asian region (Bhatti et al., 2019).

Pakistan is having 16 million ha area around the Indus basin that is irrigated by using $122 \mathrm{~km}^{3}$ of surface water annually. But this water supply is inadequate to meet the crop requirement. Additionally, 1.36 million tube wells are operating to provide $62 \mathrm{~km}^{3}$ of ground water to irrigate the crops. One million tube wells are pumping water in Punjab (Qureshi \& Perry, 2021). In order to address this water shortage issue, it is required that farmers must be provided with training skills, information and irrigation management skills. Pakistan is agrarian economy that accounts $21 \%$ of GDP. $60 \%$ of earning is possible through agriculture goods export. Pakistan's $80 \%$ of population is involved in agriculture sector (Qureshi \& Perry, 2021). So, these efforts will help Pakistan is flourishing its economy.

"Water governance doctrine refers to social, economic, administrative and political systems influencing the transboundary water use and management" (Kalair et al., 2019). IWT provides the rules and regulations for the water governance. India and Pakistan must resolve their issue through dialogues. India must refrain from adopting Harmon doctrine and provide due right to Pakistan for using water from its rivers (Kalair et al., 2019). India and Pakistan are only focusing on electricity production while planning and constructing their Hydropower projects. 
These projects can provide co-benefits but that need proper cooperation. There is a need to enhance the irrigation prospects (Tortajada \& Molden, 2021). Politics of water is considered as politics of perspective and a development discourse (Shree, 2021). Therefore, it is better to communicate and resolve the issue through dialogue.

Indian first water policy was formulated in 1987. Later the policy was revised in 2002. Indian that policy emphasized on ecological, economic and existential issues. In 2012 water policy was revised again. India is having $17 \%$ of world population but it is having $4 \%$ of renewable water resources. India is using water for domestic, agriculture and industry usages. Industrial water wastage is polluting available water resources. $80 \%$ of available water in India is used for irrigation purposes. India is facing water management issues such as floods, and drought etc. Science and technological modernization resulted into dams' construction to address water scarcity issue (Shree, 2021).

Pakistan's National Water Policy (NWP) of 2018 explained the seriousness of water scarcity issue by providing statistical data. According to the policy, Pakistan was having access to 5260 $\mathrm{m}^{3}$ surface water but in 2016 Pakistan's water availability level decreased to the $1000 \mathrm{~m}^{3}$ (Ebrahim, 2021). From these statistics it is predicted that Pakistan's available water resources in 2050 would be only $860 \mathrm{~m}^{3}$ (Ebrahim, 2021). Pakistan Council of Research in Water Resources (PCRWR) declared that "water stress line" and "water scarcity line" was crossed by Pakistan in 1990 and 2005 (Ebrahim, 2021).

NWP 2018 prompted that Pakistan is in a dire need to manage water resources by constructing water reservoirs and dams. IMF issued a report in 2015 stated that Pakistan's water demand and supply in 2025 would be 274 million-acre feet (MAF) and 191 MAF respectively (Ebrahim, 2021). The water shortage would be $83 \mathrm{MAF}$ in 2025. According to 2016 census Pakistan's population was 207.7 million. It is expected that Pakistan's population will be 395 million in 2047 (Ebrahim, 2021). Increasing population would need more water. Pakistan's water scarcity is negatively affecting agriculture sector and local people. This issue is also a source of interprovincial water conflict. Succinctly, water issue a source of conflict between India and Pakistan that need to be addressed on urgent basis.

\section{Hydro-Hegemony Framework (HHF)}

Hydro-Hegemony Framework (HHF) was used first time in 2006 by Mark Zeitoun and Jeroen Warner in their writing titled as "Hydro-hegemony - a framework for analysis of transboundary water conflicts" published in Water Policy journal (containing page no 435-460) (Zeitoun \& Warner, 2006). They applied HHF on the four River cases that are Nile, Jordan, Tigris and Euphrates. According to them hydro hegemony is concerned with hegemony exercised by states at river basin level. This hegemony is desired need of the state that can be accomplished by adopting water control strategies. These strategies include: "resource capture, integration and containment" and can be adopt through different tactics such as "coercion pressure, treaties, knowledge construction, etc." (Zeitoun \& Warner, 2006).

In the existing "weak international institutional system" (Zeitoun \& Warner, 2006) and the power asymmetry relations has forced the powerful state to exercise hegemony at the transboundary water river level. While analysing the role of hydro-hegemon state, it is noticed that it either cooperate or compete for water. Cooperation is driven because of the fact of getting benefit whereas, competition is to get dominance and inequitable water share or more share 
than the less powerful or other weaker state. The power of a state determines the level of her water control in the hydro-competition (Zeitoun \& Warner, 2006). In short, HHF illustrated the fact that there is an ongoing water competition between the states across the world. States are having the power asymmetrical relation and (hydro-hegemon) state want to get control over water resources/ flow by adopting few strategies. To be a strong hydro-hegemon state, the hydro-hegemon state adopts three sorts of strategies including "water resource capturing strategy, integration and containment."

HHF has three significant pillars to evaluate the strength of hydro-hegemon. The three pillars are of prime concerns to determine the power and authenticity of hydro-hegemon. Position, power and potential all combine to assist the state to be a hydro-hegemon. Three pillars of hydro-hegemon are riparian position, exploitation potential and power. Riparian position is the geographical position of state; either that position might be upper-streamer or the lower streamer. Exploitation potential is the infrastructure technical capability of states. Technical advancement determines the hydro-hegemony nature of the state, along with other criteria. It is the only one criterion to determine the nature of hydro-hegemon.

Third pillar is the power pillar which is having three dimensions to evaluate. First one is structural power that includes military, economic and political power. Second dimension is active stalling incentives. It is the mechanism of delaying the process of negotiation or the process through which delay the water flow to pressurize the other side. It is also considered as the ideational power of the state. Third dimension is securitization and sanctioned discourse. Securitization is associated to the concept of sanctioned discourse. In this process state illustrate the low-political issues as high-political issue. For instance, water issue is interlinked to national security and the discourse is adopted that water scarcity would lead to water war. Hydro-hegemon because of its position politicize or depoliticize certain issue to fulfil its interests. By depoliticizing or adopting silence hydro-hegemon keep certain issue off the table (Haile, 2018).

Securitization is the knowledge construction phenomenon through speech act. Hegemon state adopts it to serve its interests. The hegemon state adopts the strategy of controlling the thoughts to create and maintain its influence. In this process hype over water issue is created to make it a national security issue. For instance, mostly India is threatening to stop water supply to Pakistan and abandoning IWT. Sometime, hydro-hegemon state adopts this type of tactics just to "divert the attention of public away from serious water management issues" (Zeitoun \& Warner, 2006). Recently in the end of February 2019, India threatened Pakistan to halt water supply to Pakistan in the aftermath of Palwama case.

Hydro-hegemon state formulated a sanctioned discourse and people are constrained not to think beyond the set discourse. Powerful side or the hydro-hegemon state has the authority for sanctioning discourse. Sanctioned discourse is a framework of "knowledge construction" in the form of ideas and narratives to accomplish its (or hegemon's) interests. Hydro-hegemon "consciously emphasize or de-emphasize certain discourses to get control and to manipulate debates surrounding hydro politics that fits their objectives and interest" (Haile, 2018). In short power can be determined by state's geographical position, technical capabilities, its structural power (i.e., military, economic and political power), bargaining power and ideological power (that is possible by knowledge construction by adopting the process of speech act, securitization and sanctioned discourse). 


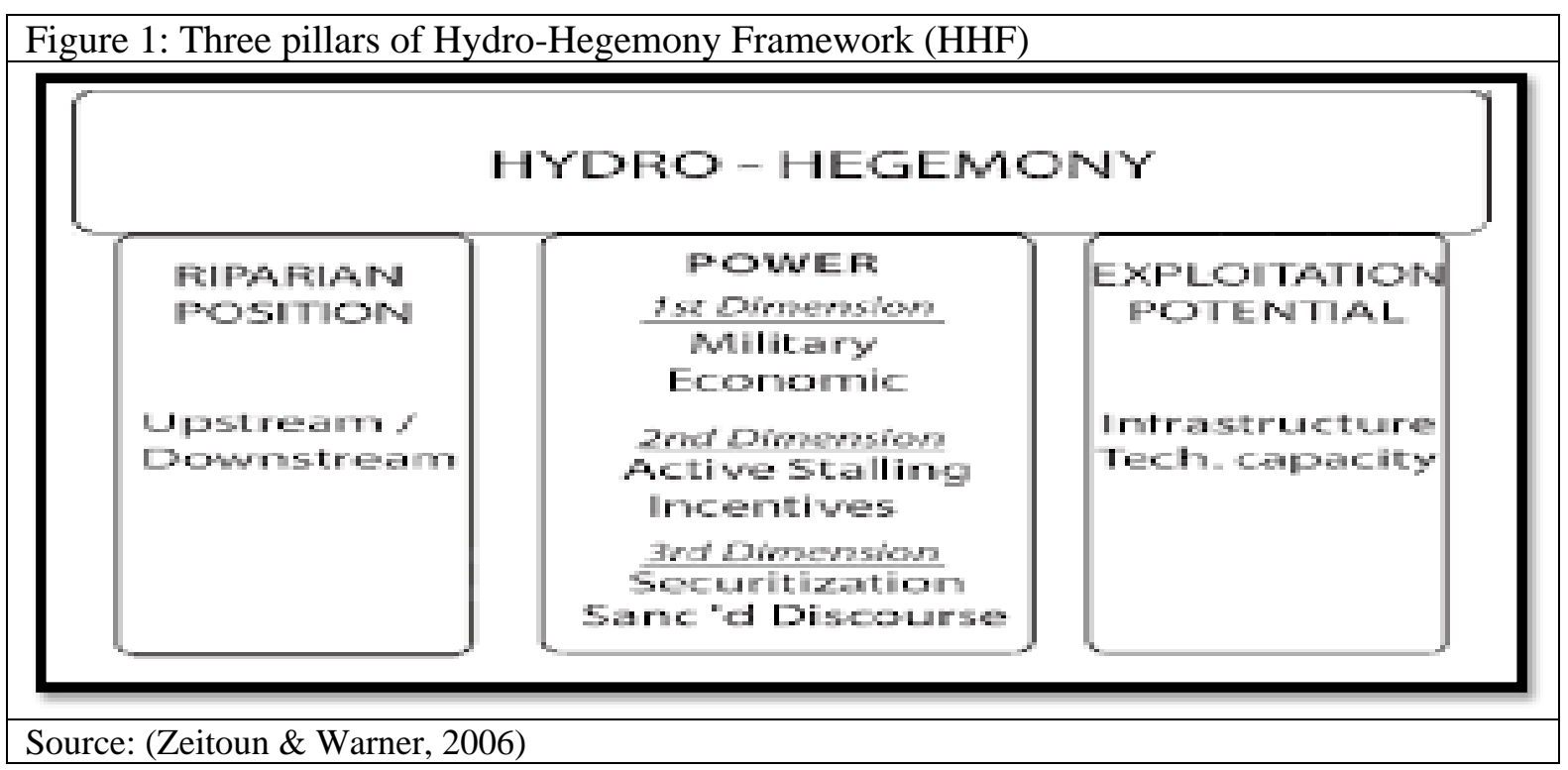

\section{Criteria of Hydro-Hegemony Framework (HHF)}

HHF is the theoretical basis to explain transboundary hydro relations of states. Water is becoming scared, and glaciers started melting due to climatic changes and environmental degradation. This water scarcity leads to water competition. States are not in the situation of power equilibrium but are facing power asymmetry. This power asymmetry forced them to adopt water control strategies and tactics to get contested control over water. This contested control of water helps the hydro-hegemon state to maintain power and fulfil its water demand in the water scare environment. This comprehensive explanation of HHF demonstrated three main elements or criteria of the theory to be noted. First is water competition, second is power asymmetry and the last is control over water. However, water control is possible through adopting few strategies and tactics (Zeitoun \& Warner, 2006).

The Hydro-Hegemon state is the one that indulges in hydraulic power politics at international river basins level. The Hydro-hegemon state tries to achieve hegemony by adopting few strategies, such as: water resource capturing strategy, integration, and containment. HHF is most appropriately applicable in the case of transboundary water conflicts if three conditions fulfil. These conditions are considerable power asymmetry, competition over water resources and control over water flow. Moreover, in India-Pakistan hydro-relation, above-mentioned three criteria are applicable.

\section{Research methodology}

For this research paper, both qualitative and quantitative research methodology was used. Deductive research methodology was adopted, where HHF theory was successfully tested in the Indo-Pakistan case. Secondary data was utilized such as books, research articles from different online engines such as Google scholar, Google, ISI Web, PubMed, NCBI, online libraries (DRSM library, HEC digital library, Wiley online library). PDF Drive.Com. Descriptive and analytic technique is used. Initially the background of study is provided in the literature review section. Later, theory was defined; its criteria and pillars are discussed. Additionally, the theory is applied in all respective and three forms of water control in India and Pakistan case are provided. 


\section{Application of criteria of HHF in India-Pakistan hydro-relations}

\subsection{Power asymmetry}

The First criteria of HHF is power asymmetry and in India-Pakistan relations, power asymmetry can be judged on three different levels. One is measured on the geographical scale. Second is technical power and the third one is structural power (such as military, economic, and political), bargaining power and ideological power.

\subsubsection{First power}

First Power is based on geographical location; India is upper-riparian states, and its geography determines its power and bestowed it the power to assert pressure on Pakistan's water flow because Pakistan is lower-streamer state. Being powerful state, India is asserting control over water flow by adopting few strategies and tactics which Pakistan are considering unfair.

\subsubsection{Second power}

The second power is technical power. India is having technical power to construct more than 5100 dams. Pakistan is lacking behind by having only 164 dams as mentioned in table 3 .

\subsubsection{Third power}

Third power is in the form of structural, bargaining and ideological power.

\section{A. Structure power}

Structural power includes economic, military, and political power

\section{A.1. Indian economic power}

Indian economic status is improving and in 2003 it was $12^{\text {th }}$ largest economy. It became $7^{\text {th }}$ in 2018 (World GDP Ranking, 2018) and now in 2019 it is the $5^{\text {th }}$ largest economy. It is estimated that by 2023 it would sustain the $5^{\text {th }}$ largest economy's status and by 2033 it would be the $3^{\text {rd }}$ largest economy. To gain the status of largest economy, India needs more energy and other sort resources including water resources. So, it is behaving as a hydro-hegemon states. Pakistan's economic power ranking is not as good as Indian economic power ranking. Pakistan's economic ranking in 2003 and in 2019 is same at the level of $44^{\text {th }}$ world economic power.

Table-1: GDP Ranking World economies

\begin{tabular}{|c|l|r|r|r|r|r|r|r|}
\hline 2019 & Country & 2033 & 2028 & 2023 & 2018 & 2013 & 2008 & 2003 \\
\hline 1 & United States & 2 & 1 & 1 & 1 & 1 & 1 & 1 \\
\hline 2 & China & 1 & 2 & 2 & 2 & 2 & 3 & 6 \\
\hline 3 & Japan & 4 & 3 & 3 & 3 & 3 & 2 & 2 \\
\hline 4 & Germany & 5 & 5 & 4 & 4 & 4 & 4 & 3 \\
\hline 5 & India & 3 & 4 & 5 & 7 & 10 & 12 & 12 \\
\hline 6 & France & 7 & 7 & 7 & 6 & 5 & 6 & 5 \\
\hline 44 & Pakistan & 27 & 37 & 44 & 41 & 48 & 50 & 44 \\
\hline
\end{tabular}

Source: (Emma, 2018) 


\section{A.2. Indian global military power}

Indian global military power ranking is the $4^{\text {th }}$ largest in the world. However, Pakistan is the $17^{\text {th }}$ largest military power globally in the year 2018 (Woody, 2018; Global Fire Power, 2019). Military power is of two main sorts i.e., conventional, and nuclear power. Conventionally parity exist between India and Pakistan but the after acquiring nuclear technology, the balance of terror concept has prevailed in the South Asia. In south Asia, nuclear deterrence prevails though an unending arm race is going on. Along with terrestrial warfighting means both states are adopting other extra-terrestrial environments to enhance their power. Both states have instigated a new space race and cyber race to meet demands of the existing world power status.

\section{B. Bargaining power}

The bargaining power of India is good, and it can be assessed by three factors. First factor is its geographical location and being an upper streamer, her position improves its bargaining power with neighbouring states. India is adopting Harmon Doctrine of absolute territorial sovereignty of being upper streamer state. So, according to this right, sovereign rights of using water belongs to upper-streamer state. Second factor is that India is blessed with experts to defends its stance in front of neutral experts, as Indian experts did in Baglihar project case. At last, Pakistan lost this case and India got the certificate to build the dam (but India has to incorporate few or three amendments that were recommended by the neutral expert). Availability of water and technical experts enhances its bargaining power in front of Indus water commission, arbitrary courts, and neutral experts.

Third factor that enhanced Indian power is its strategic relations with powerful states. These states backed India mostly. India always maintained good relations with most of the powerful states. India is the most efficient state, which is having agreements with Russia, America, Israel, Saudi-Arabia, Iran, Afghanistan, China etc. India knows how to maintain its influence in the region and make good relations with other states to enhance its bargaining power. Indian enhancing trade relation with other states are evident of its bargaining power. India growing military and economic power also enhances its barging power stature. The bargaining power or the "second face of power" aimed at getting "control over rules of game." Pakistan's weakness in the bargaining power does not means end of the game. This power can be interlinked with other issues to get the matter delayed or to get international support. In this case "weaker parties would not become weak. Neither they appear weak, nor they perceive weak." For instance, when water issue is connected to the Kashmir issue then the bargaining power might affect.

\section{Ideological power}

Ideological power is exercised by knowledge construction. Powerful state implements their ideology to serve their interests in the mind of weaker state. So, that the weaker party believe that hegemon's ideology is the rightest believe. This happened at the time of 1948s when India curtailed Pakistan's water supply and agreed to restore partial water supply after in one month on the demand of seigniorage. At that time Pakistan agreed to pay seigniorage because of Indian ideological power. India constructed the ideology that India is the upper-riparian state and has the sovereign right to control water so as a lower-riparian state Pakistan has to pay seigniorage for using water. In short it is known as "power over ideas." After acquiring all these form of power, hydro-hegemon state can write and rewrite the rules of game. 


\subsection{Competition over water flow}

The second criteria of applying HHF is to have competition over water flow in the transboundary region. The statistic of South Asian region is illustrating the fact rise in the population level and the decrease in the resources of the region. Along with other resources, water availability level to Pakistan has decreased to 1000 cubic metres per capital from the level of 5000 cubic meters per capita per annum since 1960. However, it is estimated that by 2020, the water Pakistan will get would be only 800 cubic metres per capital per annum. So, this scarcity has generated a new water competition that forced the hydro-hegemon state and other state to capture and store more water to meet with the future water demand. Pakistan also proposed the construction of few dams to fulfil its water demand. India already is third worldwide state with most dam and is also developing lot of more dams to store more water than its need and to run its hydro-power projects.

The water competition exists between India and Pakistan since independence. This water competition was noticed at the time of Kashmir war, when India halted the water supply to Pakistan from two headworks that were named as Ferozepor and Madhopur headworks on April $1^{\text {st }}, 1948$. Furthermore, India also captured Mangla Headworks (located in Mirpur district over the Jhelum River) and the Marala Headworks (situated over the Chenab River) in April 1948. These Indian capturing of water headwork strategy was because to get control over water flow to Pakistan.

Indian projects on western rivers show it is trying to get hold on water resources of Pakistan since independence. IWT provide India control of $20 \%$ of water flows through Indus River water and Pakistan got sovereignty over use of $80 \%$ of the water flows from Indus River basin (Bhatti, 2020; Mehsud et al., 2020). Water competition is because of many reasons including population growth, rising energy demand, economic need, agriculture sector need etc. World population review website indicated the fact that India is having second largest country with most population. However, Pakistan is the $6^{\text {th }}$ largest country with most population rate (World Population Review, 2019). Chinese total population is more than 1.4 billion and Indian population is 1.368 billion. Increase in population forced state to have more hydro-power generation projects. More population require more agricultural products that need more water resources. Increasing population need more water for domestic usage as well. So, increasing population rate is directly propositional to the demand of more water.

Table-2: Total Population by Country 2019

\begin{tabular}{|c|l|l|l|l|l|}
\hline Rank & Country & 2019 Population & 2018 Population & Growth Rate & Area \\
\hline 1. & China & $1,420,062,022$ & $1,415,045,928$ & $0.35 \%$ & $9,706,961 \mathrm{~km}^{2}$ \\
\hline 2. & India & $1,368,737,513$ & $1,354,051,854$ & $1.08 \%$ & $3,287,590 \mathrm{~km}^{2}$ \\
\hline 3. & USA & $329,093,110$ & $326,766,748$ & $0.71 \%$ & $9,372,610 \mathrm{~km}^{2}$ \\
\hline 4. & Indonesia & $269,536,482$ & $266,794,980$ & $1.03 \%$ & $1,904,569 \mathrm{~km}^{2}$ \\
\hline 5. & Brazil & $212,392,717$ & $210,867,954$ & $0.72 \%$ & $8,515,767 \mathrm{~km}^{2}$ \\
\hline 6. & Pakistan & $204,596,442$ & $200,813,818$ & $1.88 \%$ & $796,095 \mathrm{~km}^{2}$ \\
\hline
\end{tabular}

Source: World Population by Country, 2019

\subsection{Control over water flow}

Third criteria regarding water control that is possible by adopting strategy phenomenon. India 
being powerful state is asserting control over water flow by adopting few strategies and tactics which Pakistan considers unfair. India is the third state after US and China constructing most dams. India is having more than 5100 dams. India is also transmuting the water flow of Pakistani rivers to enhance its control over water flow. For instance, in Kishenganga project India is diverting water flow to Wullar lake and Pakistani Neelam-Jhelum hydro power project would get affected. Control over water is possible by three ways; i.e., shared water control, consolidated water control or contest water control. Strategies adopted by hydro-hegemon is water resource capturing strategy, integration and containment strategy. Tactics adopted by hydro-hegemon might be covert action, coercion pressure, military force usage, active stalling, treaties, securitization, sanctioning discourses, knowledge construction etc.

Figure 2 mentioned above provides the detail that the ultimate goal of hydro-hegemon state is to get consolidated control of water for which it is adopting (resources capturing, containment and integration) strategies. It is not only adopting strategies but also adopt different tactics (such as; covert action, coercion pressure, military force usage, active stalling, treaties, securitization, sanctioning discourses and knowledge construction) to achieve its hydrohegemon status and to ensure consolidate water control. It is having international support because of its bargaining power and geographical position. It is having the capability to mobilize financial assets and develop more dams because of its technical potential.

Figure 2: Hydro-Hegemony Framework (HHF) triad

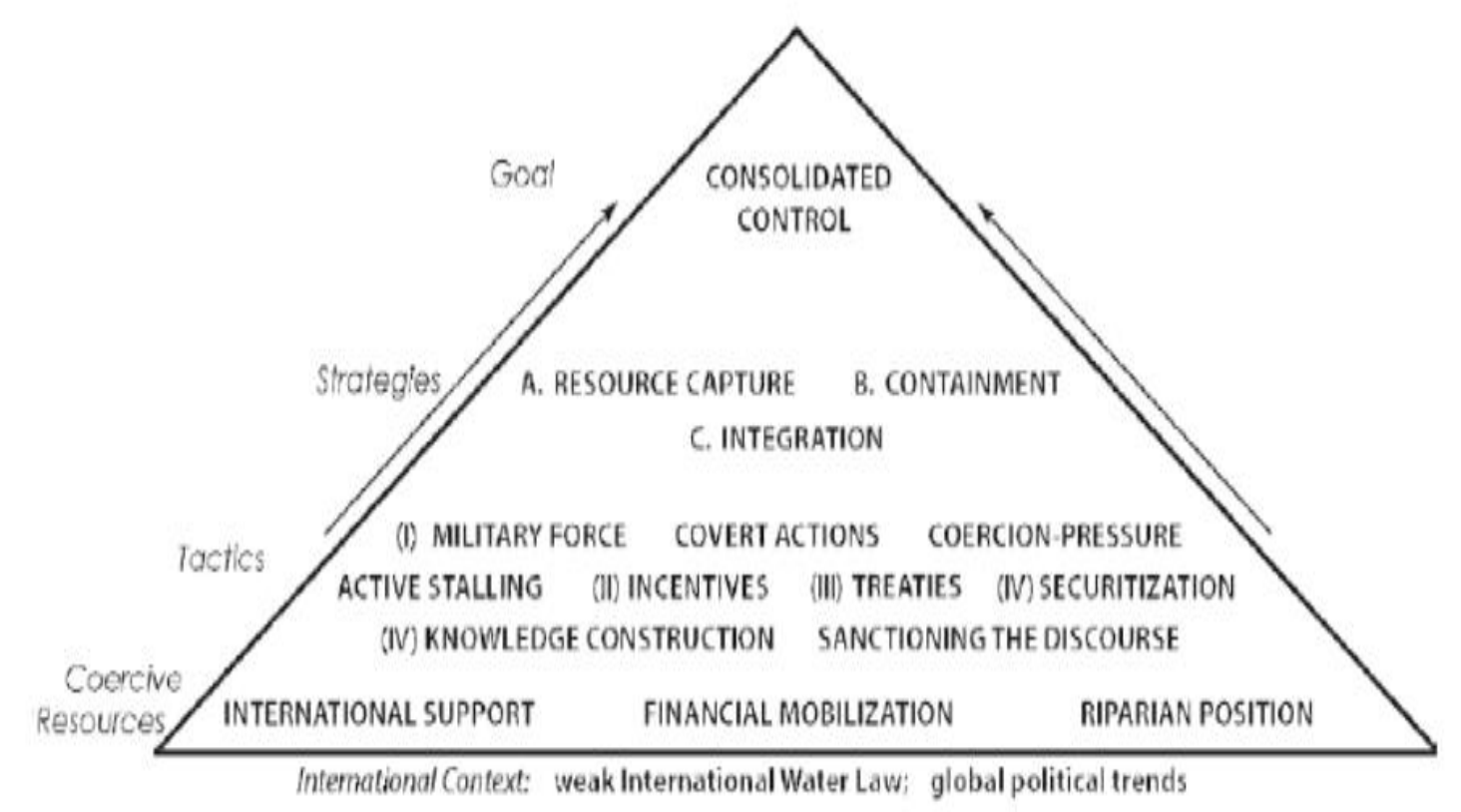

Source: (Zeitoun \& Warner, 2006)

Evaluation of the Indian strategies to get control over water resources especially through water resource capturing strategy put forward the fact that India is trying to build a lot of dams. India is not only building dams on its rivers allocated to it by IWT but also developing dams on westerns rivers allocated to Pakistan. Pakistan is having reservation over more than 52 Indian illegal dam projects to control Pakistan's water (Nation, 2010). Indian strategy of construction of dams to win water competition is proved from the statistics mentioned on International Commission on Large Dam (ICOLD) website in 2019. India is the third largest state with 5100 
dams after China (23,841 dams) and US (9,265 dams). However, Pakistan is the $27^{\text {th }}$ state in the world having 164 dams (ICOLD, 2019). Water control strategy of India is noticed in different projects in which India is trying to alter the water flow pattern. For instance, in Kishenganga project India is altering water flow and shifting water flow to Wullar lake. This Indian project is exerting negative impact for Pakistan in two ways, firstly Pakistan's NeelamJhelum hydro power project would get affected and secondly, India can flood or drought Pakistan (especially agriculture sector would get affected from Indian aforementioned project.

Figure-3 comprehensively illustrate the hydro-hegemony framework (form of hydrohegemony, water control strategies, interaction, water distribution outcome and conflict). This figure illustrates the form of hydro-hegemon. Hydro-hegemon can either have positive leadership role or can be negative role to maintain dominance. Water control strategies might be integration, resource capturing or containment. These strategies are based on the character/role/ nature/form of hydro-hegemon. The form of interaction might be of three sorts, that are shared water control, consolidated water control or contested water control. This interaction would also depend upon the form of hydro-hegemon, but interaction determine the distribution of water resources. Nature of hegemon, its strategies, its interaction and its distribution of resources determines the scenario of cooperation and conflict.

Figure 3: Hydro-Hegemony Framework: An overview

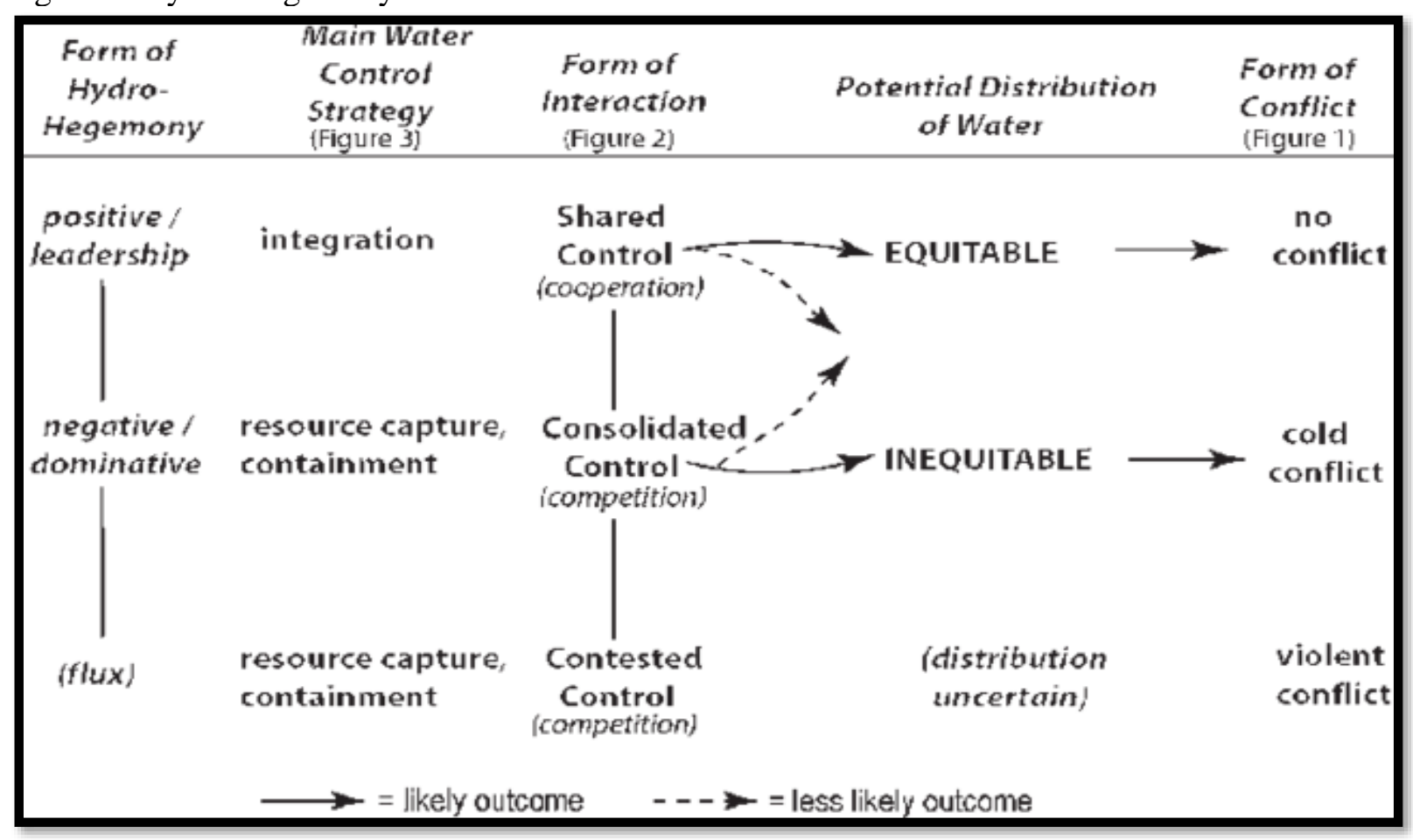

Source: (Zeitoun \& Warner, 2006)

\subsubsection{Form of hydro-interaction between India and Pakistan}

Figure 3 is applicable in the India-Pakistan hydro relations. Somewhere in history India adopted the role of positive leadership and mostly acted/played negative leadership role to maintain dominance over water resources. Water control interaction between/among states can be of three main types. For instance, shared water control, consolidated water control and contested water control interaction. 


\section{A. Shared water control}

The first scenario is of cooperation in which the hydro-hegemon state desires to get shared water control. In this scenario, positive leadership role is played by hydro-hegemon state and it adopts the strategy of integration. Hydro-hegemon state interact with other states to get shared control of water and this scenario is known as the scenario of cooperation. Both states divide equal amount of water resources and in this cooperative scenario no conflict would be noticed. Shared water control scenario in India-Pakistan water relation was noticed at the time of September 1960 when with the mediatory role of World Bank both states signed IWT (Qamar et al., 2019). It was decided that the water resources would be distributed equally on the 3:3 bases; that means three eastern rivers and three western rivers were given to India and Pakistan respectively.

\section{B. Consolidated control}

The second scenario is based on competition of states over water resources in which hydrohegemon state want to get consolidated control over water resources. In this scenario hydrohegemon would behave negatively to get dominance over water resources. Its competitive nature forced it to get consolidated or unequal control over water resources through the strategy of water resource capturing or containment. This strategy is adopted by India by constructing a lot of dams over three western rivers (assigned to Pakistan). India is constructing majority of these dams in the Indian occupied Kashmir region. To get control over water resources it is getting control over Jammu and Kashmir. India is immensely investing on dams in Kashmir region to get control over Pakistan's water supply. India can flood or drought Pakistan's land from these Indian projects over Pakistani rivers and on the same time India is illegally diverting Pakistan's water (Farid, 2017). In case of Baglihar dam on Chenab River, India is not only generating 450 Mega Watt power but India from this project would also divert more than 7,000 cusecs of the water daily from Chenab River for irrigation that is a clear defilement of IWT. Electricity generation is admissible to India in IWT from the water resources of Pakistani rivers. But India is proscribed to divert water flow from these rivers.

Indian desired to achieve the goal of getting consolidated water control is evident from the Baglihar Dam construction project. This project is a serious and vibrant violation of IWT. Indian Baglihar project allows India to store 164,000 acres feet of water. This project is a threat to Pakistan as well because Pakistani water supply would be vulnerable because from this project India would halt water supply for about 26 days. ${ }^{2}$ So, like other Indian dam projects over Pakistani rivers e.g., Tullbul, Wullar, and Kishenganga projects, India is just getting consolidated water control to get access to more water resources in the existing water competition environment. In this competitive environment the situation of cold conflict would be noticed. It took a lot of time in the resolving these conflicts. In India-Pakistan case, India is not sharing prior information before the commencement of the project and the non-cooperative nature of India took years to resolve any conflicting project.

\section{Contested control}

The third scenario is the violent conflict scenario in which the hydro-hegemon state is indulged in violent competition to get contested control over the water resources. This scenario involves uncertainty and was noticed at the time of April 01, 1948, when India stopped the water supply to Pakistan from two headworks named as Ferozepor and Madhopur headworks, positioned on 
the River Sutlej and Ravi in Kashmir respectively. India also captured two other headworks named as Mangla and Marala headworks located on river Jhelum and Chenab respectively to pressurize Pakistan in the ongoing Kashmir war of 1948. The intensity of conflict got more sever when in May 1948, Pakistani forces were mobilized for strengthening its defence. Finally, the issue was resolved when India took the issue to the UN and UNSC intervened. Both India and Pakistan accepted the UNSC resolution to institute a plebiscite in Kashmir through which Kashmiris would decide their future. In the aforementioned case India wanted to get contested control over water resources to pressurize Pakistan in the violent conflict. But due to the involvement of uncertainty the nature of conflict had become severer when on the other side Pakistan also started mobilizing its forces. But after the United Nations decision the conflict was resolved. It is noted that the Kashmir and water issue in South Asia are interconnected (Anunciação, 2013).

\section{Conclusion}

The transboundary water rivers were not separated between India and Pakistan in 1947 at the time of partition. Afterwards hydro-conflict of 1948 forced them to have hydro-regime to regulate their hydro-affairs. Hydro-cooperation was noticed in the form of IWT that was penned in September 1960 (Qamar et al., 2019) to regulate India-Pakistan hydro-relation but India is behaving as a hydro-hegemon state and initiated different disputing projects such as: Baglihar, Kishenganga, Tulbul and Wullar projects over western rivers allocated to Pakistan. IWT allowed India to have only run of river projects over western rivers but did not allow to store water or to divert water flow, but India is violating IWT by diverting water flow from western rivers (Farid, 2017). Pakistan is having reservations over Indian 52 disputed projects. Water scarcity and hydro-competition forced India to get control over water resources and flow, for that purpose it developed more than 5100 dams and became the third largest state having most dams globally.

The Indian hydro-hegemony stature is validated through the prism of hydro-hegemony framework and this framework is utterly applicable to India-Pakistan hydro-relations. Water competition is becoming severer because of the scare water resources and Indian hydrohegemonic nature. While applying Hydro-hegemony framework at the India Pakistan hydrorelation it is noted that India is playing role of negative hydro-hegemon to maintain its dominance by getting (inequitable or more) water control through resource capturing strategy because its goal is to attain consolidate water control, but this would lead to the situation of conflict. The scenario of cooperation was noticed once that was at the time of September 1960 when IWT was signed, at that time India showed the behaviour of positive leadership and adopted the strategy of shared water control. Mostly, Indian behaviour is like hydro-hegemon because of three main reasons including; its advantageous geographical position, advanced technical capability to control water and power asymmetry (based on its bargaining power, ideological and structure power). The prospects of cooperation are very less because India is not adopting the policy of shared water control, but its goal is to achieve consolidated water control that would lead to conflict scenario. Indian endeavours for accomplishing hydro-control would complicate India-Pakistan relation. 


\section{References}

Angelakis, A., Valipour, M., Ahmed, A., Tzanakakis, V., Paranychianakis, N., Krasilnikoff, J., Drusiani, R., Mays, L., El Gohary, F., Koutsoyiannis, D., Khan, S. \& Giacco, L., (2021). Water conflicts: From ancient to modern times and in the future. Sustainability, 13(8), 4237. https://doi.org/10.3390/su13084237

Anunciação, A. S. (2013). O conflito em Caxemira: Uma luta identitária e a perpetuação de um risco internacional. Doctoral Dissertation, FEUC. https://estudogeral.sib.uc.pt/handle/10316/24771

Bhatti, M. N. (2020). Politics of Water Resource Management in the Indus River Basin: A Study of the Partition of Punjab. Liberal Arts and Social Sciences International Journal (LASSIJ), 4(2), 60-70. https://doi.org/10.47264/idea.lassij/4.2.6

Bhatti, M. N., Mustafa, G., \& Waris, M. (2019). Challenges to Indus Waters Treaty and options for Pakistan. Global Regional Review, 4(4), 249-255. https://doi.org/10.31703/grr.2019(IV-IV).27

Ebrahim, Z., (2021). Is Pakistan Running Dry? In: A. Ranjan, ed., Water issues in Himalayan South Asia: Internal challenges, disputes and transboundary tensions, (1st ed.) Palgrave Macmillan, 153-182. https://doi.org/10.1007/978-981-32-9614-5_7

Emma. (2018, December 28). GDP rankings of the world's largest economies, 2019. CEOWORLD Magazine. https://ceoworld.biz/2018/12/28/gdp-rankings-of-theworlds-largest-economies-2019/

Farid, R., Ahmad, I., \& Khan, R. Z. N. (2017). Design of upstream overflow Cofferdam of Patrind Hydropower project. In HYDROPOWER (p. 86).

Global Fire Power. (2019). Military strength ranking 2019. https://www.globalfirepower.com/countries-listing.asp

Haile, F. G. (2018). Unravelling the Gift of the Nile: Examining the domestic and international determinants of Ethiopian counter-hegemony in the Eastern Nile River basin. Doctoral Dissertation, King's College, London. https://kclpure.kcl.ac.uk/portal/files/103159019/2018_Haile_Frezer_Getachew_093 1517_ethesis.pdf

Iqbal, A. R. (2010). Water wars and navigating peace over Indus River basin. National Defence University, Islamabad.

ICOLD. (2019). International Commission on Large Dam (ICOLD). http://www.icoldcigb.org/article/GB/world_register/general_synthesis/number-of-dams-by-countrymembers)

Javed, M., Rasool, I. \& Mustafa, G., (2021). Water politics between Pakistan and India: An analysis. Research Journal of Social Sciences and Economics Review (RJSSER), 2(1), 195-199. https://doi.org/10.36902/rjsser-vol2-iss1-2021(195-199)

Kalair, A., Abas, N., Ul Hasan, Q., Kalair, E., Kalair, A. \& Khan, N., (2019). Water, energy and food nexus of Indus Water Treaty: Water governance. Water-Energy Nexus, 2(1), 10-24. https://doi.org/10.1016/j.wen.2019.04.001

Mehsud, M. I., Jan, A., Khan, T. A. (2020). War or Peace on the Rivers of South Asia? Liberal Arts and Social Sciences International Journal (LASSIJ), 4(1), 242-254. https://doi.org/10.47264/idea.lassij/4.1.21

Michel, D. (2020). Water Conflict Pathways and Peacebuilding strategies. United States Institute of Peace.

Mirza, M. N. (2016). Indus water disputes and India-Pakistan relations. Doctoral Dissertation, Department of Political Science, South Asia Institute, University of Heidelberg, 
Germany.

http://archiv.ub.uni-

heidelberg.de/volltextserver/20915/1/Mirza\%20PhD\%20Dissertation\%20for\%20hei $\underline{\text { DOK.pdf }}$

Nation. (2010). India Plans 52 Projects to Control Pakistani's Water. https://nation.com.pk/pakistan-news-newspaper-daily-englishonline/Islamabad/30Mar-2010/India-plans-52-projects-to-control-Pakistans-water

Nazakat, A, R., Rehman, F., \& Wani, M. R. (2015). Indus Water Treaty between Pakistan and India: From conciliation to confrontation. Dialogue (Pakistan), 10(2). 166-181.

Price, G., Alam, R., Hasan, S., Humayun, F., Kabir, M. H., Karki, C. S., ... \& Tuladhar, S. (2014). Attitudes to water in South Asia. Royal Institute of International Affairs. http://seine.oieau.fr/oieau.fr/sites/seine.oieau.fr.oieau.fr.eaudoc/files/33114.pdf

Qamar, M., Azmat, M. \& Claps, P. (2019). Pitfalls in transboundary Indus Water Treaty: a perspective to prevent unattended threats to the global security. Perspective NPJ Clean Water, 2(1), 1-9.

Qureshi, A. \& Perry, C. (2021). Managing water and salt for sustainable agriculture in the Indus Basin of Pakistan. Sustainability, 13(9), 5303. https://doi.org/10.3390/su13095303

Qureshi, W. A. (2017). Water as a human right: A case study of Pakistan and India water conflict. Penn State Journal of Law and International Affairs, 5(2), 371-397. https://elibrary.law.psu.edu/jlia/vol5/iss2/6/

Ranjan, A. (2016). Disputed waters: India, Pakistan and the transboundary rivers. Studies in Indian Politics, 4(2), 191-205. https://doi.org/10.1177/2321023016665529

Shree, R., (2021). Mapping the water disputes in India: Nature, issues and emerging trends. In: A. Ranjan, ed., Water issues in Himalayan South Asia internal challenges, disputes and transboundary tensions, 1st ed. Singapore: Palgrave Macmillian, pp.103-124.

Sridhar, S. (2008). Kashmir and water: Conflict and cooperation. Swords and Ploughshares, Winter 2007-8. https://www.ideals.illinois.edu/bitstream/handle/2142/15473/Kashmir_and_Water_ Conflict_and_Cooperation.pdf?sequence $=2 \&$ is Allowed $=\mathrm{y}$

Tortajada, C., \& Molden, D. (2021). Hydropower as a catalyst for regional cooperation in South Asia. International Journal of Water Resources Development, 37(3), 362-366. https://doi.org/10.1080/07900627.2021.1887558

Woody, C. (2018, November 22). The most powerful militaries in the world in 2018. Business Insider. https://www.businessinsider.com/most-powerful-militaries-in-the-worldranked-2018-11\#17-pakistan-9.

World GDP Ranking. (2018). Projected GDP ranking. Statistics Times. http://statisticstimes.com/economy/projected-world-gdp-ranking.php

World Population Review. (2019). 2019 World population by country. http://worldpopulationreview.com/

Zeitoun, M., \& Warner, J. (2006). Hydro-hegemony-a framework for analysis of transboundary water conflicts. Water Policy, 8(5), 435-460. https://doi.org/10.2166/wp.2006.054

\section{Notes:}

${ }^{1} 796,095 \mathrm{~km}^{2}$ is Pakistan's total area while excluding Azad Kashmir and Gilgit-Baltistan but Pakistan's total area is $881,912 \mathrm{~km}^{2}$ after including Azad Kashmir and Gilgit-Baltistan.

${ }^{2}$ Especially during the month of December, January and February. 